\title{
Modification of Cardiac Phenotype in Tbx1 Hypomorphic Mice
}

\author{
Takatoshi Tsuchihashi, Reina Ishizaki, Jun Maeda, Akimichi Shibata, \\ Keiko Uchida, Deepak Srivastava, and Hiroyuki Yamagishi
}

\section{Keywords}

Tbx $1 \cdot$ Truncus arteriosus • Environmental modification

Congenital heart disease is still the leading cause of death within the first year of life. Our lab forces on understanding the morphology of congenital heart disease. Outflow tract anomalies, including abnormal alignment or septation, account for $30 \%$ of all congenital heart disease. To solve the developmental problem of these defects, we are interested in the role of the second heart field (SHF) that gives rise to the outflow tract structure.

$T B X 1$, a member of the T-box family of transcription factors, is a major genetic determinant of $22 q 11$ deletion syndrome (22q11DS) in human. $22 q 11 D S$ is the most frequent chromosomal microdeletion syndrome in human and characterized by abnormal development of the cardiac outflow tract, such as persistent truncus arteriosus (PTA), tetralogy of Fallot, interrupted aortic arch, and ventricular septal defects.

In the developing murine heart, Tbx 1 is expressed in the SHF, but not in the cardiac neural crest cells (NCCs). Our past experiments suggested that sonic hedgehog signal was necessary for maintenance of the Tbxl expression in the pharyngeal mesoderm including the SHF [1]. Tbxl null $\left(T b x 1^{-1-}\right)$ mice demonstrated PTA reminiscent of the 22q11DS heart phenotype. We generated

T. Tsuchihashi • R. Ishizaki • J. Maeda • A. Shibata • K. Uchida • H. Yamagishi $(\bowtie)$

Department of Pediatrics, Division of Pediatric Cardiology, Keio University School of Medicine,

Tokyo, Japan

e-mail: hyamag@keio.jp

D. Srivastava

Gladstone Institute of Cardiovascular Disease, San Francisco, CA 94158, USA

Department of Pediatrics and Department of Biochemistry and Biophysics, University of California, San Francisco, San Francisco, CA 94158, USA

T. Nakanishi et al. (eds.), Etiology and Morphogenesis of Congenital Heart Disease, DOI 10.1007/978-4-431-54628-3_28 

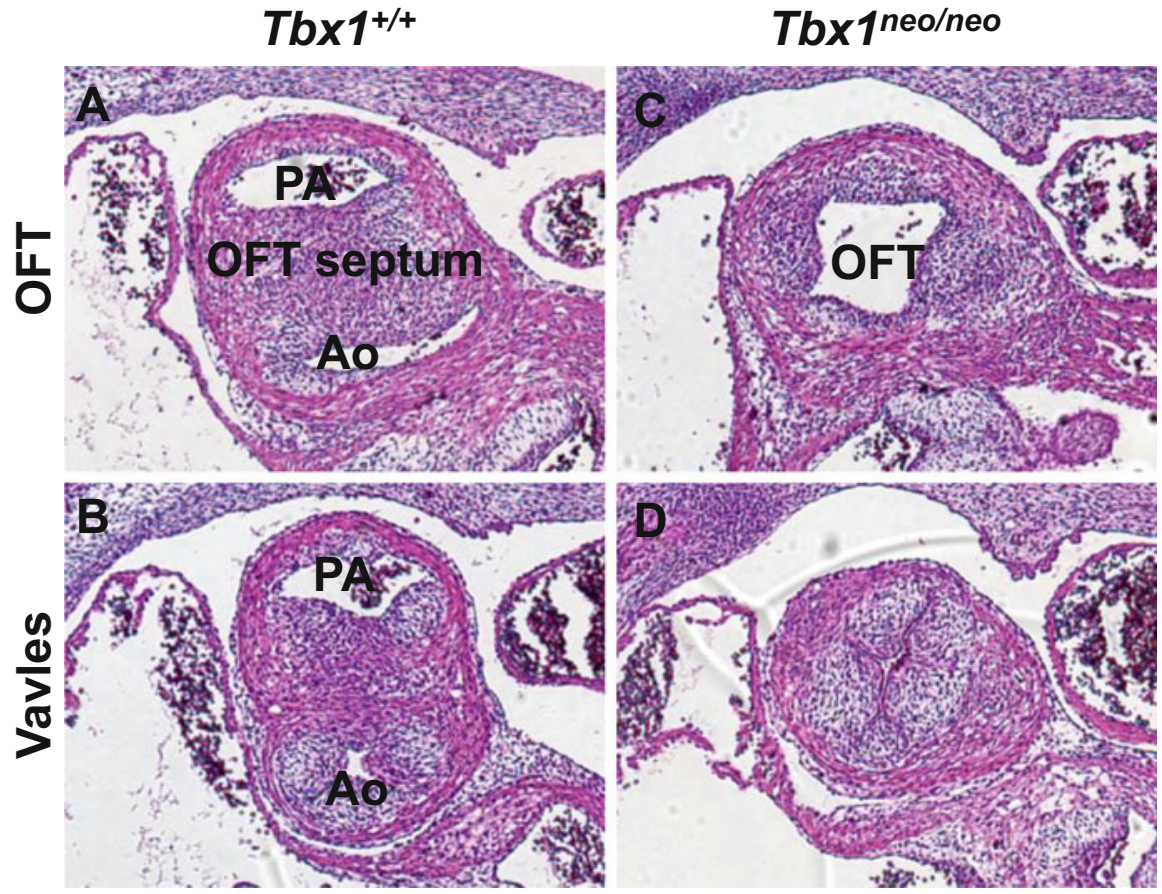

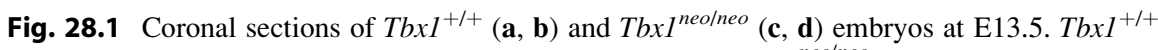
showed the normal outflow tract (OFT) septation, whereas $T b x I^{\text {neo/neo }}$ demonstrated PTA. Ao Aorta, $P A$ pulmonary artery

Tbx1 hypomorphic allele (Tbx $I^{\text {neo/+ }}$ ) [2] for attempting to recapitulate the human genotype and phenotype correlation. Mice homozygous for this hypomorphic allele expressed around $25 \%$ of Tbx 1 mRNA compared to wild-type mice. We demonstrated that Tbx1 is a dosage-dependent gene and believe that the Tbx1 dosage can be affected by genetic and/or environmental modifiers because of highly variable phenotype of 22q11DS instead of the relatively uniform chromosomal microdeletion. We are trying to create the phenotype variability of PTA in this hypomorphic model (Fig. 28.1) by application of environmental modifiers. Through this study, we would better understand the interaction between the gene dosage and environmental factors during the development of outflow tract defects.

Open Access This chapter is distributed under the terms of the Creative Commons AttributionNoncommercial 2.5 License (http://creativecommons.org/licenses/by-nc/2.5/) which permits any noncommercial use, distribution, and reproduction in any medium, provided the original author(s) and source are credited.

The images or other third party material in this chapter are included in the work's Creative Commons license, unless indicated otherwise in the credit line; if such material is not included in the work's Creative Commons license and the respective action is not permitted by statutory regulation, users will need to obtain permission from the license holder to duplicate, adapt or reproduce the material. 


\section{References}

1. Yamagishi H, Maeda $\mathrm{J}, \mathrm{Hu} \mathrm{T}$, et al. Tbx 1 is regulated by tissue-specific forkhead proteins through a common Sonic hedgehog-responsive enhancer. Gene Dev. 2003;17:269-81.

2. Hu T, Yamagishi H, Maeda J, et al. Tbx1 regulates fibroblast growth factors in the anterior heart field through a reinforcing autoregulatory loop involving forkhead transcription factors. Development. 2005;131:5491-502. 